\title{
PENGGUNAAN ALAT PERAGA KALENDER MATRIK PELANGI UNTUK MENINGKATKAN HASIL BELAJAR MATEMATIKA SISWA KELAS VI A SDN KUTA BATEE
}

\author{
Evi Zahara
}

\author{
SD Negeri Kuta Batee \\ e-mail: evi7112@yahoo.com
}

\begin{abstract}
ABSTRAK
Penelitian ini bertujuan untuk mengetahui dan mendeskripsikan peningkatan hasil belajar matematika materi FPB dan KPK dengan penggunaan alat peraga Kalender Matrik Pelangi pada siswa kelas VIA SDN Kuta Batee semester I tahun ajaran 2017/2018. Jenis penelitian ini termasuk penelitian action research. Subyek penelitian ini adalah siswa kelas VIA SDN Kuta Batee yang berjumlah 23 orang. Hasil penelitian ini menunjukkan: Penggunaan alat peraga Kalender Matrik Pelangi dalam pembelajaran materi FPB dan KPK pada siswa kelas VIA SDN Kuta Batee tahun ajaran 2017/2018 dapat meningkatkan hasil belajar siswa. Hal ini dibuktikan dengan peningkatan nilai rata-rata kelas dan persentase ketuntasan siswa pada setiap tahapan penelitian. Pada tahap pra siklus nilai rata-rata siswa mencapai 56,08 dan pada siklus I meningkat menjadi 73,47 kemudian meningkat lagi pada siklus II menjadi 81,30. Sementara persentase ketuntasan siswa pada tahap pra siklus baru mencapai 30,43\% sedangkan pada siklus I ketuntasan siswa meningkat menjadi 60,86\% kemudian meningkat lagi pada siklus II menjadi 86,95\%. Penggunaan alat peraga Kalender Matrik Pelangi dalam pembelajaran matematika materi FPB dan KPK pada siswa kelas VIA SDN Kuta Batee dapat meningkatkan kualitas proses pembelajaran. Hal ini dibuktikan dengan peningkatan aktivitas siswa selama proses pembelajaran dari siklus I sebesar 51,8\% menjadi $85,7 \%$ pada siklus II dengan kategori baik. Berdasarkan penelitian yang telah dilaksanakan, maka dapat disimpulkan bahwa penggunaan alat peraga Kalender Matrik Pelangi dapat meningkatkan hasil belajar matematika materi FPB dan KPK siswa kelas VIA SDN VIA SDN Kuta Tahun Ajaran 2017/2018.
\end{abstract}

Kata Kunci: Alat Peraga Kalender Matrik Pelangi, Hasil Belajar Matematika.

\begin{abstract}
This study aims to find out and describe the increase in mathematics learning outcomes of FPB and KPK material with the use of teaching aids in the Rainbow Matrix Calendar for VIA students at SDN Kuta Batee in the first semester of the 2017/2018 school year. This type of research includes action research. The subjects of this study were VIA class students at SDN Kuta Batee, which numbered 23 people. The results of this study indicate: The use of the Rainbow Matrix Calendar teaching aids in learning FPB and KPK material for VIA class students at SDN Kuta Batee 2017/2018 academic year can improve student learning outcomes. This is evidenced by the increase in the value of the class average and the percentage of completeness of students at each stage of the study. In the pre-cycle stage, the average value of students reached 56.08 and in the first cycle increased to 73.47 then increased again in the second cycle to 81.30. While the percentage of completeness of students in the pre-cycle stage only reached $30.43 \%$ while in the first cycle the completeness of students increased to $60.86 \%$ then increased again in the second cycle to $86.95 \%$. The use of the Rainbow Matrix Calendar teaching aids in the mathematics learning of FPB and KPK material in VIA class students at SDN Kuta Batee can improve the quality of the learning process. This is evidenced by the increase in student activity during the
\end{abstract}


learning process from the first cycle of $51.8 \%$ to $85.7 \%$ in the second cycle in the good category. Based on the research that has been carried out, it can be concluded that the use of teaching aids in the Rainbow Matrix Calendar can improve the mathematics learning outcomes of the FPB and KPK students of VIA Elementary School SDN Kuta Academic Year 2017/2018.

Keywords: Aids in the Rainbow Matrix Calendar, Mathematics Learning Results

\section{PENDAHULUAN}

Sebagai disiplin ilmu mempunyai andil yang besar dalam pengembangan dunia teknologi yang kini telah mencapai puncak kecanggihan dalam mengisi berbagai dimensi kebutuhan hidup manusia. Era global yang ditandai dengan kemajuan teknologi informatika, industri otomotif, perbankan, dan dunia bisnis lainnya, menjadi bukti nyata adanya peran matematika dalam revolusi teknologi.

Mata pelajaran matematika di sekolah dasar merupakan salah satu program pembelajaran yang bertujuan untuk mempersiapkan siswa agar sanggup menghadapi perubahan keadaan dalam kehidupan yang selalu berkembang, melalui latihan bertindak atas dasar pemikiran secara logis, rasional, kritis, cermat, jujur, dan efektif.

Melihat betapa besar peran matematika dalam kehidupan, maka tugas guru di sekolah adalah membina dan mempersiapkan peserta didik agar dapat menggunakan pola pikir matematika dalam kehidupan sehari-harinya, juga dalam mempelajari berbagai ilmu pengetahuan lainnya.

Kenyataan yang kita temukan di lapangan menunjukkan bahwa hasil belajar matematika selalu berada di tingkat bawah dibandingkan dengan mata pelajaran lainnya.

Salah satu materi pelajaran yang sangat berkaitan dengan pemecahan masalah dalam kehidupan sehari-hari yang diajarkan di sekolah dasar mulai dari kelas IV sampai dengan kelas VI adalah materi Faktor Persekutuan Terbersar (FPB) dan Kelipatan Persekutuan Terkecil (KPK).

Hasil identifikasi masalah yang penulis temukan pada siswa kelas kelas VIA SDN Kuta Batee adalah hanya 7 orang $(30,43 \%)$, dari 23 siswa yang mendapatkan nilai sama dengan atau lebih besar dari KKM (65) dan selebihnya 16 orang $(69,56 \%)$ nilainya masih di bawah nilai KKM. Hal tersebut menunjukkan bahwa hasil belajar matematika yang diperoleh siswa kelas VIA SDN Kuta Batee pada materi FPB dan KPK masih rendah.

Rendahnya hasil belajar disebabkan karena selama ini guru menerapkan model pembelajaran kooperatif dengan metode pemberian tugas latihan soal tanpa penggunaan media atau alat peraga yang tepat dan menarik perhatian siswa, dan cenderung membosankan. Hal tersebut menyebabkan siswa kurang memahami konsep FPB dan KPK dengan baik, sehingga hasil belajar siswa rendah.

Pelaksanaan Matematika model pembelajaran kooperatif dengan metode pemberian contoh dan latihan soal diganti dengan model pembelajaran aktif menggunakan alat peraga Kalender Matrik Pelangi. Proses pembelajaran aktif diharapkan dapat membantu meningkatkan keaktifan siswa dalam pembelajaran. Melalui penggunaan alat peraga Kalender Matrik Pelangi diharapkan siswa dapat memahami konsep-konsep FPB dan KPK dengan baik. Guru hanya berperan sebagai pembimbing, penyedia alat peraga serta media yang diperlukan dalam pembelajaran dan pemberi motivasi, sehingga siswa dapat lebih aktif dan bersemangat dalam mempelajari materi FPB dan KPK dalam suasana belajar yang menyenangkan. Dengan demikian diharapkan siswa dapat memahami materi FPB dan KPK serta dapat menyelesaikan masalah sehari-hari yang berkaitan dengan FPB dan KPK. Melalui pemahaman konsep FPB dan KPK yang baik tentu saja akan dapat meningkatkan hasil belajar materi FPB dan KPK.

Temuan ini yang kemudian mendasari penulis untuk melaksanakan perbaikan 
pembelajaran melalui Penelitian Tindakan Kelas (PTK) untuk meningkatkan hasil belajar matematika materi FPB dan KPK pada siswa kelas VIA SDN Kuta Batee. Untuk meningkatkan hasil belajar siswa maka diperlukan pembelajaran yang menarik dan melibatkan siswa. Ada beberapa hal yang menjadi perhatian dalam pelaksanaan penelitian tersebut antara lain alat peraga Kalender Matrik pelangi, hasil belajar, dan konsep FPB dan KPK.

Menurut Nasution (2003:100) "alat peraga adalah alat pembantu dalam mengajar agar efektif". Sejalan dengan itu ahli lain mengemukakan bahwa alat peraga adalah alat untuk memberikan pelajaran atau yang dapat diamati melalui panca indera. Alat peraga merupakan salah satu dari media pendidikan. Alat peraga adalah alat untuk membantu proses belajar mengajar agar proses komunikasi dapat berhasil dengan baik dan efektif.

Sedangkan Alat peraga matematika adalah seperangkat benda konkret yang dirancang, dibuat, dihimpun atau disusun secara sengaja yang digunakan untuk membantu menanamkan atau mengembangkan konsep-konsep atau prinsip-prinsip dalam matematika (Iswaji 2003:1).

Dengan melihat peranan alat peraga dalam pengajaran, maka pelajaran matematika merupakan pelajaran yang paling membutuhkan alat peraga, karena pada pelajaran ini siswa berangkat dari yang abstrak yang akan diterjemahkan kesesuatu yang konkret.

Secara umum fungsi alat peraga adalah sebagai berikut.

a. Sebagai media dalam menanamkan konsep-konsep matematika.

b. Sebagai media dalam memantapkan pemahaman konsep.

c. Sebagai media untuk menunjukkan hubungan antara konsep matematika dengan dunia di sekitar kita, serta aplikasi konsep dalam kehidupan nyata.

Menurut Soekarno dalam Romzah (2006:19) kriteria pemakaian alat peraga adalah sebagai berikut.
1) Macam-macam alat peraga ditinjau dari segi wujudnya alat peraga matematika dapat dikelompokan menjadi:

a. Alat peraga benda asli

Alat peraga matematika pada dasarnya anak beajar melalui alat yang konkrit. Untuk memahami konsep abstrak anak memerlukan benda-benda konkret (riil) Adalah yang digunakan sebagai alat peraga seperti : buah, bola, pohon, kubus dari kayu dan sebagainya.

b. Alat peraga tiruan

Adalah benda bukan asli yang digunakan sebagai alat perga seperti: gambar, tiruan jantung manusia dari balon dan selang plastik dan sebagaiya.

2) Sifat-sifat alat peraga

Dasar proses pembelajaran adalah pengalaman dan proses belajar yang efektif serta permanen diperoleh dari pengalaman yang bersifat konkret dan langsung. Namun pengalaman yang demikian tidak terlalu dapat diberikan kepada siswa, harus dirancang sedemikian rupa untuk dapat memilih pengganti pengalaman tadi dengan media pembelajaran, termasuk didalamnya adalah penyajian proses pembelajaran dengan mengguanakan alat peraga.

Berdasarkan uraian-uraian tersebut jelaslah bahwa media atau alat bantu mengajar adalah segala sesuatu yang dapat digunakan untuk menyalurkan pesan dan dapat merangsang pikiran, perasaan, perhatian dan kemauan siswa sehingga dapat mendorong terjadinya proses belajar pada diri siswa.

Pemakaian alat peraga dalam proses pembelajaran akan mengkomunikasikan gagasan yang bersifat konkret, disamping juga membantu siswa mengintegrasikan pengalaman-pengalaman sebelumnya. Dengan demikian diharapkan alat peraga dapat memperlancar proses belajar siswa serta mempercepat pemahaman dan memperkuat daya ingat didalam diri siswa. Selain itu alat peraga diharapkan menarik perhatian dan membangkitkan minat serta motivasi siswa dalam belajar, dengan demikian pemakaian alat peraga akan sangat mempengaruhi keefektifan proses 
pembelajaran yang diberikan kepada siswasiswi. Unsur metode dan alat juga merupakan unsur yang tidak dapat dilepaskan dari unsur lainnya yang berfungsi sebagai cara atau teknik untuk mengantarkan bahan pengajaran agar sampai pada tujuan.

Alat Peraga Kalender Matrik Pelangi adalah alat peraga yang penulis gunakan dalam penelitian ini berupa Kalender dan Matrik Pelangi, yang digunakan untuk menentukan KPK dan FPB dengan bantuan spidol warna (hitam, merah, dan biru) jika ingin menentukan KPK dan FPB dari dua bilangan menggunakan spidol dua warna dan menggunakan tiga warna berbeda jika ingin menentukan KPK dan FPB dari tiga bilangan.

Adapun langkah-langkah cara menggunakan alat peraga Kalender adalah sebagai berikut:

a. Untuk menentukan FPB dari dua bilangan

Misalnya: Tentukan FPB dari 24 dan 18

Maka kita hanya perlu mencontreng masing-masing faktor dari 24 dan 18. Tanggal berapa yang mendapat dua contrengan dan merupakan faktor terbesar dari 24 dan 18, itulah FPB nya.

b. Untuk menentukan KPK dari dua bilangan

Misalnya:

Adi belajar matematika setiap dua hari dan Ida belajar matematika setiap tiga hari. Jika pada tanggal 2 Mei 2017 mereka belajar matematika bersama, maka kapan lagi mereka akan belajar matematika secara bersamaan?

Untuk memecahkan soal ini, kita contreng pada tanggal yang merupakan kelipatan 2 menggunakan spidol warna hitam dan kita contreng pada tanggal yang merupakan kelipatan 3 menggunakan spidol warna merah seperti contoh:

Adi $\square 2,4,6,8,10,12,14,16,18 \ldots$

Ida $\square 3,6,9,12,15,18, \ldots$

Tanggal 12 merupakan kelipatan persekutuan terkecil (KPK) dari 2 dan 3

Jadi pada tanggal 12 Mei 2017 mereka akan belajar bersama lagi.
Alat peraga Matrik Pelangi adalah alat peraga yang dirancang dan dibuat sendiri oleh penulis menggunakan kardus bekas yang dilapisi dengan kertas perda berwarnawarni seperti merah, kuning dan hijau. Pada bagian atasnya ditempelkan selembar kertas karton pink yang diberi baris dan kolom menyerupai matrik kemudian dilapisi sampul plastik bening agar pada saat menulis bilangan menggunakan spidol non permanen dapat dihapus atau ditulis kembali untuk penyelesaian soal-soal FPB dan KPK lainnya.

Alat peraga Matrik Pelangi ini digunakan untuk menentukan FPB dan KPK bilangan-bilangan yang lebih besar yang tidak dapat ditentukan menggunakan alat peraga kalender.

Cara menentukan FPB dan KPK menggunakan alat peraga Matrik Pelangi sama dengan metode tabel yaitu hanya dengan membagi bilangan yang dicari menggunakan bilangan prima $(2,3,5,7,11$, ...dst).

Contoh: Tentukan FPB dan KPK dari bilangan 45 dan 60 !

\begin{tabular}{|c|c|c|}
\hline 45 & 60 & \\
\hline \hline 45 & 30 & 2 \\
\hline \hline 45 & 15 & 2 \\
\hline \hline 15 & 5 & $\mathbf{3}$ \\
\hline \hline 5 & 5 & 3 \\
\hline \hline 1 & 1 & $\mathbf{5}$ \\
\hline
\end{tabular}

Jadi:

FPB dari 45 dan $60=3 \times 5=15$ dan KPK dari 45 dan $60=22 \times 32 \times 5 \times=180$

Menurut Hamalik (2004:30) Hasil belajar menunjukan prestasi belajar, sedangkan prestasi belajar itu merupakan indikator adanya perubahan tingkah laku siswa. Hasil belajar sebagai tanda terjadinya perubahan tingkah laku.

Penelitian ini bertujuan untuk meningkatkan hasil belajar matematika materi FPB dan KPK pada siswa kelas VIA SDN Kuta Batee tahun ajaran 2017/2018 dengan menggunakan alat peraga Kalender Matrik Pelangi. 


\section{METODE PENELITIAN}

Penelitian ini bermaksud mengungkapkan suatu upaya memperbaiki proses pembelajaran dengan menggunakan Alat Peraga Kalender Matrik Pelangi untuk meningkatkan hasil belajar matematika materi FPB dan KPK pada Siswa Kelas VIA SDN Kuta Batee tahun ajaran 2017/2018, maka penggunaan pendekatan penelitian tindakan kelas (PTK) dipandang relevan dalam penelitian ini.

Penelitian Tindakan kelas terdiri dari tiga kata,yaitu "penelitian", "tindakan", dan "kelas". Penelitian adalah kegiatan mencermati suatu objek dengan menggunakan aturan metodologi tertentu untuk memperoleh data atau informasi yang bermanfaat untuk meningkatkan mutu suatu hal menarik minat dan penting bagi peneliti. Tindakan adalah suatu gerak kegiatan yang sengaja dilakukan dengan tujuan tertentu, yang dalam penelitian berbentuk rangkaian siklus kegiatan. Kelas adalah sekelompok siswa yang dalam waktu yang sama menerima pelajaran yang sama oleh guru. (Kunandar 2009:45)

Penelitian tindakan kelas dapat didefenisikan sebagai suatu penelitian tindakan yang dilakukan oleh guru sekaligus sebagai peneliti dikelasnya atau bersamasama dengan orang lain atau kolaborasi dengan jalan merancang, melaksanakan dan merefleksikan tindakan secara kolaboratif dan partisipatif yang bertujuan untuk memperbaiki atau meningkatkan mutu atau kualitas proses pembelajaran dikelasnya melalui suatu tindakan tertentu dalam suatu siklus. (Kunandar 2009 : 45)

Penelitian ini dilakukan di SDN Kuta Batee Trienggadeng Pidie Jaya, adapun subjek penelitian ini adalah siswa-siswi kelas VA yang berjumlah 23 orang. Dalam penelitian tindakan ini, teknik pengumpulan data yang digunakan penulis adalah lembar observasi atau pengamatan sehubungan dengan apa yang telah ditetapkan. Hasil observasi ini merupakan gambaran keadaan umum didalam kelas selama pembelajaran meliputi kegiatan guru maupun aktivitas belajar siswa. Indikator aktivitas siswa dikembangkan sendiri oleh peneliti yang diadaptasi dari Sardiman (2009 : 101), yang dibatasi pada aspek: (a) memperhatikan, (b) berbicara, (c) mendengarkan, (d) menulis, (e) activitas mental, dan (f) emosional.

Dalam penelitian ini, jenis data yang digunakan adalah: 1) Data kualitatif yang be-rupa dokumen dan hasil dokumentasi. Dokumen berisi kurikulum yaitu daftar nama siswa kelas VA SDN Kuta Batee, Silabus dan Rencana Pelaksanaan Pembelajaran (RPP) kelas V, 2) Data kuantitatif berupa nilai siswa sebelum dan sesudah dilaksanakan penelitian. Sumber data yang digunakan dalam penelitian ini berasal dari hasil observasi, tes, dan dokumentasi. Teknik yang digunakan untuk mengumpulkan data dalam penelitian ini meliputi lembar observasi, dokumen, tes, dan perekaman foto. Adapun teknik yang digunakan dalam memeriksa validitas data dalam penelitian ini adalah:

1. Triangulasi data atau sumber yaitu dengan membandingkan dan mengecek balik derajat kepercayaan suatu informasi yang telah diperoleh melalui berbagai sumber berbeda yaitu: a). Observasi dari proses pembelajaran; b). Silabus dan RPP; c). Tes soal pecahan; e). Foto kegiatan belajar menggunakan alat peraga Kalender Matrik Pelangi.

2. Triangulasi teknik metode yaitu mengecek data kepada sumber yang sama dengan teknik yang berbeda. Data yang diperoleh dari observasi dicek dengan hasil tes dan foto.

Menurut Sarwiji Suwandi (2010: 61), teknik analisis data yang digunakan untuk menganalisis data-data yang telah berhasil dikumpulkan antara lain dengan teknik deskriptif komparatif (statistik deskriptif komparatif) dan teknik analisis kritis. Teknik deskriptif komparatif untuk data kuantitatif, sedangkan teknik analisis kritis digunakan untuk data kualitatif.

\section{HASIL PENELITIAN}

a. Deskripsi Hasil Penelitian Pra Siklus

Pada kondisi pra siklus, diketahui rendahnya hasil belajar siswa yang ditunjukkan 
dari tes awal tentang kelipatan dan faktor bilangan yaitu dari 23 siswa hanya $30,43 \%$ atau 7 siswa yang mendapat nilai di atas batas Kriteria Ketuntasan Minimal (KKM). Sedangkan yang lainnya berada di bawah batas KKM. Adapun data hasil penelitian pada pra siklus adalah sebagai berikut:

Tabel 1. Ketuntasan Belajar Siswa Hasil Tes Pra Siklus

\begin{tabular}{|l|c|c|}
\hline \multirow{2}{*}{ Hasil Belajar } & \multicolumn{2}{|c|}{$\begin{array}{c}\text { Hasil Tes Pra } \\
\text { Siklus (Skor Dasar) }\end{array}$} \\
\cline { 2 - 3 } & $\begin{array}{c}\text { Banyak } \\
\text { Siswa }\end{array}$ & $\begin{array}{c}\text { Persentas } \\
\text { e }\end{array}$ \\
\hline $\begin{array}{l}\text { Jumlah siswa tuntas } \\
\text { belajar (skor } \geq 65)\end{array}$ & 7 & $30,43 \%$ \\
\hline $\begin{array}{l}\text { Jumlah siswa tidak } \\
\text { tuntas belajar (skor } \\
\leq \text { 65) }\end{array}$ & 16 & $69,57 \%$ \\
\hline Rata-rata kelas & \multicolumn{2}{|c|}{$\mathbf{5 6 , 0 8}$} \\
\hline
\end{tabular}

b. Deskripsi Hasil Penelitian Siklus I

Nilai rata-rata kelas yang diperoleh untuk materi FPB dan KPK siswa pada siklus I sebesar 73,47 dengan nilai tertinggi 90 dan nilai terendah 50. Siswa yang mendapat nilai di atas KKM hanya 60,86\% atau 14 siswa dari jumlah keseluruhan 23 siswa, sedangkan siswa yang mendapat nilai di bawah KKM sebanyak 39,14 \% atau 9 siswa dari jumlah keseluruhan 23 siswa.

Kemampuan guru dalam mengajar pada siklus I memperoleh persentase ratarata $60 \%$ dalam kriteria cukup. Aktivitas siswa dalam siklus I memperoleh persentase rata-rata $52 \%$ dalam kriteria kurang. Ketuntasan siswa baru mencapai 60,68\%.

Hasil Penelitian pada siklus I dapat dilihat seperti pada tabel berikut ini:

Tabel 2. Ketuntasan Belajar Siswa Hasil Tes Siklus I

\begin{tabular}{|l|c|c|}
\hline \multirow{2}{*}{ Hasil Belajar } & \multicolumn{2}{|c|}{$\begin{array}{c}\text { Hasil Tes Siklus I } \\
\text { (Skor Dasar) }\end{array}$} \\
\cline { 2 - 3 } & $\begin{array}{c}\text { Banyak } \\
\text { Siswa }\end{array}$ & $\begin{array}{c}\text { Persentase } \\
(\%)\end{array}$ \\
\hline $\begin{array}{l}\text { Jumlah siswa } \\
\text { tuntas belajar } \\
\text { (skor } \geq 65)\end{array}$ & 14 & $60,86 \%$ \\
\hline
\end{tabular}

\begin{tabular}{|c|c|c|}
\hline $\begin{array}{lr}\text { Jumlah } & \text { siswa } \\
\text { tidak } & \text { tuntas } \\
\text { belajar } & \text { (skor } \leq \\
65) & \end{array}$ & 9 & $39,14 \%$ \\
\hline Rata-rata kelas & \multicolumn{2}{|c|}{73,47} \\
\hline
\end{tabular}

c. Deskripsi Hasil Penelitian Siklus II

Kemampuan guru dalam mengajar pada siklus II memperoleh persentase sebesar $87,5 \%$ dalam kriteria sangat baik. Aktivitas siswa dalam siklus II memperoleh persentase sebesar $85,7 \%$ dalam kriteria baik. Ketuntasan siswa mencapai $86,95 \%$.

Nilai rata-rata kelas yang diperoleh untuk materi FPB dan KPK siswa pada siklus II sebesar 81,30 dengan nilai tertinggi 100 dan nilai terendah 60. Siswa yang mendapat nilai di atas KKM 86,95\% atau 20 siswa dari jumlah keseluruhan 23 siswa, sedangkan siswa yang mendapat nilai di bawah KKM sebanyak 13,05 \% atau 3 siswa dari jumlah keseluruhan 23 siswa. Dari analisis siklus II tersebut, maka tidak perlu dilakukan tindakan siklus berikutnya karena hasilnya sudah memenuhi indikator keberhasilan yaitu $\geq 80 \%$ dari jumlah keseluruhan siswa mendapat nilai di atas KKM (65).

Tabel 1. Ketuntasan Belajar Siswa Hasil Tes Pra Siklus

\begin{tabular}{|l|c|c|}
\hline \multirow{2}{*}{ Hasil Belajar } & \multicolumn{2}{|c|}{$\begin{array}{c}\text { Hasil Tes Pra Siklus } \\
\text { (Skor Dasar) }\end{array}$} \\
\cline { 2 - 3 } & $\begin{array}{l}\text { Banyak } \\
\text { Siswa }\end{array}$ & Persentase \\
\hline $\begin{array}{l}\text { Jumlah siswa } \\
\text { tuntas belajar } \\
\text { (skor } \geq 65)\end{array}$ & 20 & $86,95 \%$ \\
\hline $\begin{array}{l}\text { Jumlah siswa } \\
\text { tidak tuntas } \\
\text { belajar (skor } \leq 65)\end{array}$ & 3 & $13,05 \%$ \\
\hline Rata-rata kelas & \multicolumn{2}{|c|}{$\mathbf{8 1 , 3 0}$} \\
\hline
\end{tabular}

\section{PEMBAHASAN}

Berdasarkan pengamatan dan analisis data, hasil penelitian menunjukkan bahwa 
materi FPB dan KPK siswa kelas kelas VA SDN Kuta Batee tahun pelajaran 2017/2018 mengalami peningkatan pada setiap siklus. Dari hasil penelitian menunjukkan hasil belajar matematika konsep pecahan pada kondisi sebelum tindakan jumlah siswa yang tuntas (nilai $\geq 65$ ) sebanyak 7 siswa dari 23 siswa dengan rata-rata nilai 56,08 dengan ketuntasan belajar siswa hanya 30,43\%. Setelah digunakan Alat peraga Kalender Matrik Pelangi pada siklus I, siswa yang tuntas (nilai $\geq 65$ ) meningkat menjadi 14 siswa dengan rata-rata kelas 73,47 dengan ketuntasan siswa mencapai $60,86 \%$. Meskipun pada siklus I sudah ada peningkatan namun belum mencapai indikator kinerja yang ingin dicapai yaitu jumlah siswa yang tuntas mencapai $80 \%$. Tidak berhasilnya tindakan pada siklus I dikarenakan berbagai faktor dan diperbaiki pada siklus II. Setelah diadakan perbaikan pada siklus II, jumlah siswa yang tuntas meningkat yaitu 20 siswa dengan nilai ratarata kelas 81,30 dengan ketuntasan belajar $86,95 \%$. Namun masih ada 3 siswa yang belum tuntas, ini disebabkan karena kemampuan siswa yang sulit dalam menerima pelajaran dan pemahaman konsep pecahan siswa rendah. Namun penelitian dinyatakan berhasil karena siswa yang tuntas (nilai $\mathrm{KKM} \geq 65$ ) mencapai 86,95 \% telah melebihi indikator kinerja penelitian yaitu $80 \%$.

Pemahaman siswa terbentuk dari pengalaman langsung dimana siswa belajar secara lebih konkret dan menemukan sendiri konsep materi tentang FPB dan KPK menggunakan alat peraga kalender matrik pelangi, sehingga akan lebih memudahkan siswa dalam memahami, mengingat konsep, dan menyelesaikan masalah sehari-hari yang berkaitan dengan FPB dan KPK, guru juga lebih intensif memberikan bimbingan pada kelompok-kelompok dalam diskusi dan memotivasi siswa agar lebih berani dalam menyampaikan pendapat ketika persentasi. Guru mengintruksikan dengan jelas kepada semua kelompok agar membagi tugas terlebih dahulu sehingga semua siswa bekerja, merasa bertanggung jawab dan waktu tidak terbuang sia-sia. Hal ini sejalan dengan pernyataan Kemp dan Dayton (Arsyad, 2011:21-23) bahwa peran guru ketika melakukan pembelajaran menggunakan alat peraga tidak lagi terpusat pada penjelasan bahan pelajaran yang berulang-ulang. Guru dapat memusatkan perhatian kepada aspek penting lain dalam proses pembelajaran, misalnya sebagai konsultan siswa. Peran guru lebih banyak pada motivasi dan mendorong kegiatan siswa serta sebagai pembimbing dan fasilitator bagi siswa dalam proses rekonstruksi ide dan konsep matematika.

\section{SIMPULAN DAN SARAN \\ a. Simpulan}

Berdasarkan hasil penelitian penggunaan alat peraga kalender matrik pelangi pada siswa kelas VA SDN Kuta Batee tahun pelajaran 2017/2018 dalam kegiatan pembelajaran dengan materi FPB dan KPK, dapat diambil simpulan bahwa Penggunaan alat peraga Kalender Matrik Pelangi dalam pembelajaran materi FPB dan KPK pada siswa kelas VIA SDN Kuta Batee tahun ajaran 2017/2018 dapat meningkatkan hasil belajar siswa. Hal ini dibuktikan dengan peningkatan nilai rata-rata kelas dan persentase ketuntasan siswa pada setiap tahapan penelitian. Pada tahap pra siklus nilai rata-rata siswa mencapai 56,08 dan pada siklus I meningkat menjadi 73,47 kemudian meningkat lagi pada siklus II menjadi 81,30. Sementara persentase ketuntasan siswa pada tahap pra siklus baru mencapai $30,43 \%$ sedangkan pada siklus I ketuntasan siswa meningkat menjadi $60,86 \%$ kemudian meningkat lagi pada siklus II menjadi 86,95\%. Penggunaan alat peraga Kalender Matrik Pelangi dalam pembelajaran materi FPB dan KPK pada siswa kelas VIA SDN Kuta Batee tahun ajaran 2017/2018 dapat meningkatkan kualitas proses pembelajaran. Hal ini dibuktikan dengan peningkatan aktivitas siswa selama proses pembelajaran dari siklus I sebesar $51,8 \%$ menjadi $85,7 \%$ pada siklus II dengan kategori baik. 


\section{b. Saran}

Berdasarkan hasil penelitian yang diperoleh dari uraian sebelumnya agar proses belajar mengajar Matematika lebih efektif dan lebih memberikan hasil yang optimal bagi siswa, maka disampaikan saran sebagai berikut:

1. Pembelajaran menggunakan alat peraga ternyata menarik perhatian siswa dan mampu merangsang siswa untuk terlibat aktif dalam proses pembelajaran sehingga hasil belajar dapat meningkat. Akan lebih baik jika guru menggunakan alat peraga juga pada materi yang lain selain FPB dan KPK, agar siswa dapat memahami lebih baik terhadap materi yang diajarkan.

2. Perlu adanya kerja sama antara Kepala Sekolah dan guru untuk bersama-sama dalam pengadaan dan pemanfaatan fasiltas media pembelajaran untuk anak didiknya sehingga dapat menunjang hasil belajar.

\section{DAFTAR PUSTAKA}

Arikunto, Suharsimi dkk. 2009. Penelitian Tindakan Kelas. Jakarta: Bumi Aksara

Arsyad, Azhar. 2011. Media Pembelajaran. Jakarta: Rajawali Pers.

Hamalik, Oemar, 2004. Perencanaan Pengajaran Berdasarkan Pendekatan Sistem, Jakarta: Bumi Aksara.

Iswaji, 2003. Media dan Alat Peraga Matematika, Bandung: Remaja Rosdakarya.

Kunandar. 2009. Langkah mudah penelitian Tindakan Kelas, Jakarta: Rajawali Pers.

Nasution, N, 2003. Didaktik Asas-Asas Mengajar, Jakarta: Bumi Aksara
Sarwiji Suwandi. 2010. Penelitian Tindakan Kelas dan Penulisan Karya Ilmiah. Surakarta: UNS Press.

Soekarno, Romzah, 2006. Media Belajar, Jakarta: Raja Grafindo Persada. 